\title{
Effect of 3-year education in the Main Fire Service School on the fitness level of students
}

\author{
Andrzej Tomczak', Jerzy Bertrandt' ${ }^{2}$, Anna Kłos ${ }^{2}$, Wiesława Szymańska ${ }^{3}$, Wanda Stankiewicz ${ }^{2}$ \\ ${ }^{1}$ Faculty of Tourism and Recreation, Warsaw School of Tourism and Hospitality Management, Poland \\ 2 Department of Hygiene and Physiology, Military Institute of Hygiene and Epidemiology, Warsaw, Poland \\ ${ }^{3}$ Department of Health, Ministry of Internal Affairs and Administration, Warsaw, Poland
}

Tomczak A, Bertrandt J, Kłos A, Szymańska W, Stankiewicz W. Effect of 3-year education in the Main Fire Service School on the fitness level of students. Ann Agric Environ Med. 2017; 24(4): 628-631. doi: 10.5604/12321966.1232765

\begin{abstract}
Introduction and objective. The aim of the study was to determine changes in the fitness level among students of the Main Fire Service School during 3-year's education.

Methods. A total of 75 male and 5 female students took part in the study. Fitness level measurements were carried out before beginning the studies (Measurement 0 ) and after the $1^{\text {st }}, 2^{\text {nd }}$ and $3^{\text {rd }}$ years at the school (Measurement $1,2,3$ ).

The following tests were performed to estimate level of physical fitness for men: pull-ups on a bar, a $50 \mathrm{~m}$ sprint and 1,000 $\mathrm{m}$ run, and for women: sit-ups, medical ball $(2 \mathrm{~kg})$ throw from above the head and a $4 \times 10 \mathrm{~m}$ shuttle run.

Results. General fitness level (average number of points from 3 attempts) of the male and female students improved. Improvement of fitness level between Measurement 0 (male students 60.3p..77.58; female students 61.60p. \pm 3.08 ), and Measurements 1, 2, 3 (men 64.59p. $\pm 6.87 ; 64.41 p . \pm 7.17 ; 64.03 p . \pm 7.65$ and women 68.40p. $\pm 1.99 ; 66.67 p . \pm 2.36 ; 68.87 \pm 1.87$ respectively), was found. The same relationship was found while analysing results of individual competitions. Only speed endurance (anaerobic-aerobic) assessed during Measurement 0 at $64.03 p . \pm 10.23$, decreased after the $1^{\text {st }}$ year at the school (Measurement $1-59.29$ p. \pm 14.14 ) and remained on the same level during Measurements 2 and $3(60.25 p . \pm 11.20$ and $58.56 p$. \pm 12.80 , respectively).

Conclusion. Speed endurance (anaerobic-aerobic) is a capability which decreased among the students in the subsequent years. Because this capability highly correlates with activities that a fire-fighter will perform during rescue operations, it should be treated as a matter of priority during physical education classes in the Main Fire Service School.
\end{abstract}

Key words

physical fitness, fire-fighters, physical education

\section{INTRODUCTION}

It is widely known that firefighters should be physically fit to perform rescue operations efficiently, and many studies have confirmed that there is a relationship between physical fitness and overall performance of the essential tasks of the professional firefighter $[1,2]$. It was found that firefighters who are physically fit are better able their perform essential duties [3].

Rescue operations are performed in specialist clothing that restrict movements and enhance tiredness $[4,5,6]$; therefore, undertaking such tasks requires considerable strength, endurance and coordination. Rescue operations consist of such actions as carry equipment, dragging certain objects, covering short distances running, climbing ladders, clearing a path for oneself and performing many other precise actions while operating specialist equipment (climbing stairs, hose dragging, carrying equipment, raising ladders, forcing entry, carrying/dragging those rescued) $[7,8,9]$.

Training the students to undertake increased physical activity as a factor shaping physical efficiency and allowing prolongation of the efficiency of the body should be one of the main objectives of physical education in the Main Fire Service School. There are enormous possibilities to shape health-promoting attitudes, especially among students

Address for correspondence: Andrzej Tomczak, Warsaw School of Tourism and Hospitality Management, Poland

E-mail: a.tomczak@vistula.edu.pl

Received: 19 July 2013; accepted: 22 September 2014; first published on January residing in barracks. During the studies they should acquire knowledge about a healthy lifestyle, i.e. practicing exercises, proper nutrition and the influence of stimulants on the body. Care of fitness is another aspect. Physical activity profitably effects the release of stress caused by professional work (participation in rescue operations), and also influences the state of health state, especially taking into consideration cardio-vascular diseases $[10,11,12,13]$. Recognizing these benefits and professional requirements, fire-fighters have the possibility to participate in physical education classes during work, and should be subject to an annual assessment of their efficiency and physical fitness [14].

Observations concerning the assessment of the level of physical fitness of fire-fighters and fire-fighter candidates have been conducted for years. In 1999, Rakowski et al. conducted a study to assess the level of physical fitness of candidates for the Main Fire Service School, estimated based on 3 test attempts (pull-ups on a bar, a $50 \mathrm{~m}$ sprint, 1,000 m run). Candidates for the Main Fire Service School achieved better results than those obtained by 19 -year-old Polish youths in an attempt to force the muscles of the shoulder girdle and arm and speed, but worse during cross-country endurance $[9,15]$. Other studies regarding the impact of the participation of fire-fighters in physical education classes on the level of physical fitness, however, revealed an improvement in physical fitness $[8,16]$.

The aim of the study was to determine level of changes in fitness among students from the Main Fire Service School during 3-year's education. 


\section{MATERIALS AND METHODS}

Participants. A total of 75 male and 5 female students from the Main Fire Service School took part in a study. Detailed anthropometric data are given in Table 1.

Table 1. Anthropometrical data of examined persons

\begin{tabular}{|c|c|c|c|c|}
\hline \multicolumn{5}{|l|}{ MALE $(n=75)$} \\
\hline $\begin{array}{l}\text { Measurement } \\
\text { No. }\end{array}$ & $\begin{array}{l}\text { Age (SD) } \\
\text { [year] }\end{array}$ & $\begin{array}{l}\text { Body height } \\
{[\mathrm{cm}]}\end{array}$ & $\begin{array}{l}\text { Body mass } \\
{[\mathrm{kg}]}\end{array}$ & $\begin{array}{c}\text { BMI } \\
{\left[\mathrm{kg} / \mathrm{m}^{2}\right]}\end{array}$ \\
\hline 0 & $19.4 \pm 1.00$ & $179.7 \pm 5.73$ & $76.4 \pm 6.89$ & $23.6 \pm 1.87$ \\
\hline 1 & $20.2 \pm 1.08$ & $180.0 \pm 6.89$ & $77.2 \pm 7.59$ & $23.9 \pm 1.95$ \\
\hline 2 & $21.3 \pm 1.02$ & $180.4 \pm 5.75$ & $79.1 \pm 8.60$ & $24.3 \pm 2.23$ \\
\hline 3 & $21.9 \pm 1.12$ & $181.0 \pm 5.97$ & $80.1 \pm 8.37$ & $24.4 \pm 2.27$ \\
\hline \multicolumn{5}{|l|}{ FEMALE $(n=5)$} \\
\hline $\begin{array}{l}\text { Measurement } \\
\text { No. }\end{array}$ & $\begin{array}{l}\text { Age (SD) } \\
\text { [year] }\end{array}$ & $\begin{array}{l}\text { Body height } \\
{[\mathrm{cm}]}\end{array}$ & $\begin{array}{l}\text { Body mass } \\
{[\mathrm{kg}]}\end{array}$ & BMI $\left[\mathrm{kg} / \mathrm{m}^{2}\right]$ \\
\hline 0 & $19.2 \pm 0.44$ & $162.6 \pm 3.10$ & $59.9 \pm 4.75$ & $22.6 \pm 1.47$ \\
\hline 1 & $19.6 \pm 0.54$ & $162.8 \pm 3.07$ & $59.4 \pm 4.37$ & $22.4 \pm 1.73$ \\
\hline 2 & $20.2 \pm 0.44$ & $163.2 \pm 2.65$ & $59.0 \pm 4.89$ & $22.16 \pm 1.56$ \\
\hline 3 & $21.2 \pm 0.50$ & $163.6 \pm 2.71$ & $59.3 \pm 1.89$ & $22.17 \pm 1.18$ \\
\hline
\end{tabular}

The study protocol was approved by the Ethics Committee of the Military Institute of Hygiene and Epidemiology (Permission No. 2/2011).

Programme training. Physical education classes were carried out during studies. The programme entailed 30 hours of physical education classes each semester ( 2 hours per week), and consisted of: strength training, volleyball, basketball, soccer, swimming, and cross-country running.

Test methods. Measurements of the level of physical fitness were conducted prior to beginning the first year of study (Measurement No. 0), after the $1^{\text {st }}$ year of study (Measurement No. 1), after the $2^{\text {nd }}$ year of study (Measurement No. 2), and finally, after the $3^{\text {rd }}$ year of study (Measurement No. 3).

The following tests were performed to estimate physical fitness level of men:

1) pull-ups on a bar;

2) $50 \mathrm{~m}$ sprint;

3) $1,000 \mathrm{~m}$ run.

The following tests were performed to estimate the level of physical fitness of the women:

1) sit-ups;

2) medicine ball (2 kg) throw from over the head;

3) $4 \times 10 \mathrm{~m}$ shuttle run.

Description of the tests given made in the Directive of the Minister of Internal Affairs and Administration of 27 October 2005 on the scope, manner and frequency of periodic preventive medical examinations and periodic physical fitness assessment of fire-fighters serving in the State Fire Service [14].

Data analysis. All data are presented as means \pm SD. The Kolmogorow-Smirnow's test was used to check the normality of distributions.
The mean values of between-measurements differences were assessed using the ANOVA test. Statistica 6.0 software was used in data analysis with the level of significance set at $\mathrm{p}<0.05$.

\section{RESULTS}

The average number of points achieved for 3 competitions at the beginning of the study (Measurement 0), differed significantly from the average number of points obtained in later years (Measurements 1, 2, 3) (Tab. 2). The same relationship was found while analysing detailed variables (1,000 m run, $50 \mathrm{~m}$ sprint, pull-ups on a bar, sit-ups, medicine ball throw, $4 \times 10 \mathrm{~m}$ shuttle run) between the initial measurement (Measurement 0 ), and measurements made in the subsequent years of study (Tab. 2).

Table 2. Average $( \pm S D)$ values recorded in performed tests

\begin{tabular}{lcccc}
\hline Value & $\begin{array}{c}\text { Measure- } \\
\text { ment 0 }\end{array}$ & $\begin{array}{c}\text { Measure- } \\
\text { ment 1 }\end{array}$ & $\begin{array}{c}\text { Measure- } \\
\text { ment 2 }\end{array}$ & $\begin{array}{c}\text { Measure- } \\
\text { ment 3 }\end{array}$ \\
\hline Male (n=75) & & & & \\
\hline 1,000 m run [min.] & $3.15 \pm 0.17^{*}$ & $3.24 \pm 0.21$ & $3.26 \pm 0.22$ & $3.25 \pm 0.23$ \\
1,000 m run [points] & $64.03 \pm 10.23$ & $59.29 \pm 14.14$ & $60.25 \pm 11.20$ & $58.56 \pm 12.80$ \\
\hline 50 m sprint [s] & $6.95 \pm 0.25^{*}$ & $6.60 \pm 0.23$ & $6.66 \pm 0.23$ & $6.60 \pm 0.24$ \\
50 m sprint [points] & $58.31 \pm 10.29$ & $70.21 \pm 4.95$ & $68.59 \pm 7.08$ & $69.87 \pm 5.88$ \\
\hline Pull- ups on a bar & $14.47 \pm 6.33^{*}$ & $16.27 \pm 4.88$ & $16.88 \pm 5.49$ & $16.29 \pm 5.28$ \\
[number] & $58.57 \pm 14.24$ & $64.27 \pm 10.61 *$ & $64.40 \pm 12.21$ & $63.65 \pm 11.75$ \\
Pull-ups on a bar [points] & & & & \\
\hline Average No. of points & $60.30 \pm 7.58^{*}$ & $64.59 \pm 6.87$ & $64.41 \pm 7.17$ & $64.03 \pm 7.65$ \\
\hline Female (n=5) & & & & \\
\hline Sit-ups [number] & $20.00 \pm 0.0^{*}$ & $58.40 \pm 2.61$ & $47.20 \pm 15.59$ & $56.0 \pm 3.16$ \\
Sit-ups [points] & $75.0 \pm 0.0$ & $75.0 \pm 0.0$ & $75.0 \pm 0.0$ & $75.0 \pm 0.0$ \\
\hline Medicine ball (2 kg) & & & & \\
throw from above the & & & & \\
head [m] & $7.23 \pm 7.10^{*}$ & $8.12 \pm 0.39$ & $7.80 \pm 0.45$ & $8.24 \pm 0.39$ \\
Medicine ball (2 kg) throw & $36.60 \pm 10.33$ & $55.20 \pm 5.97$ & $50.0 \pm 7.07$ & $56.60 \pm 5.59$ \\
from above the head & & & & \\
[points] & & & & \\
\hline 4x10 m shuttle run [s] & $11.90 \pm 0.65^{*}$ & $11.07 \pm 0.5$ & $11.03 \pm 0.4$ & $11.19 \pm 0.46$ \\
4x10 m shuttle run [points] & $73.20 \pm 4.02$ & $75.0 \pm 0.0$ & $75.0 \pm 0.0$ & $75.0 \pm 0.0$ \\
\hline Average No. of points & $61.60 \pm 3.08^{*}$ & $68.40 \pm 1.99$ & $66.67 \pm 2.36$ & $68.87 \pm 1.87$ \\
\hline * p<0.05 difference between 0 and 1,2,3 measurements & & \\
\hline & & & & \\
\hline
\end{tabular}

After the first year of study, number of students qualified as 'outstanding' considerably increased and was maintained at the same level in the subsequent years, whereas the number of students qualified as 'poor' decreased after the first year, and then in the following years steadily increased. The number of 'pass marks' also increased. In turn, female students revealed a systematic increase in fitness level, and on the last year of study all of them achieved the 'outstanding' level (Tab. 3).

\section{DISCUSSION}

Fire-fighters, as well as the other officers of other branches of the uniformed services, are trained to act in a changing and challenging environment. To prepare themselves for the fulfilment of their tasks, every individual officer participates in physical education classes. They shape a suitable fitness level that enables the fulfilment of tasks on an optimal level 
Table 3. List of number of verbal appraisals expressed by examined persons [11]

\begin{tabular}{lcccc}
\hline MALE $(\mathbf{n}=\mathbf{7 5})$ & \multicolumn{1}{c}{} & & \\
\hline APPRAISAL & Year 2009 & Year 2010 & Year 2011 & Year 2012 \\
\hline Outstanding & 24 & 49 & 43 & 45 \\
\hline Very good & 19 & 10 & 15 & 12 \\
\hline Good & 12 & 6 & 7 & 6 \\
\hline Pass mark & 10 & 6 & 3 & 4 \\
\hline Poor & 10 & 4 & 7 & 8 \\
\hline Fail & 0 & 0 & 0 & 0 \\
\hline FEMALE (n=5) & Year 2009 & Year 2010 & Year 2011 & Year 2012 \\
\hline APPRAISAL & 1 & 4 & 2 & 5 \\
\hline Outstanding & 2 & 1 & 3 & 0 \\
\hline Very good & 2 & 0 & 0 & 0 \\
\hline Good & 0 & 0 & 0 & 0 \\
\hline Pass mark & 0 & 0 & 0 & 0 \\
\hline Poor & 0 & 0 & 0 & 0 \\
\hline Fail & & & & \\
\hline & & 4 & & \\
\hline
\end{tabular}

during fire-fighting activities, or removing the consequences of road, train or plane crashes.

Therefore, the development of physical fitness, achieved mainly during physical education classes, is very important. Unfortunately, studies have not confirmed that the implementation of physical education classes in the Main Fire Service School effects an increase in physical fitness.

It is typical that improvement in overall physical fitness occurred only after the first year of study, but the level of physical fitness achieved was maintained in the subsequent years. It can be assumed that physical education classes were not carried out in accordance with the principles of the gradation of difficulty in the physical effort and exercises. The students' involvement in the process aimed at increasing of physical fitness was probably much higher in the first year than in the following years.

Having accepted the criteria of the Directive of the Minister of Internal Affairs and Administration, during studies at the Main Fire Service School, about 20\% of students did not achieve the outstanding or very good mark [14]. If they did not achieve this standard during the 3-year's studies, it is probable that they would also never have achieved it during further service, which may have negative consequences when fulfilling duty tasks (rescue operations).

Another alarming issue is the decrease in speed endurance (anaerobic-aerobic) of students during the study. During physical education classes in the Main Fire Service School, this ability should be treated as a priority (from $400 \mathrm{~m}$ sprints to $1,000 \mathrm{~m}$ runs). According to the research by Matthew et al. (2004), anaerobic endurance significantly correlates with the typical activities performed by fire-fighters during rescue operations (hose pulling, dragging victims, stair climbing, equipment hoisting) [17].

A controversial issue, which also applies to the other branches of the uniformed services, is the structure of physical fitness tests for fire-fighters. There is no justification for the differentiation of tests which take gender into account. One succinct phrase - 'same job, same standard' - should justify the use of the same physical fitness tests for officers (soldiers) regardless of gender [18, 19]. However, analysis of currently used fitness tests for fire-fighters revealed some paradoxes: while men complete the $1,000 \mathrm{~m}$ run, $50 \mathrm{~m}$ sprint and pull-ups on a bar, women perform sit-ups, medicine ball throwing and a $4 \times 10 \mathrm{~m}$ shuttle run. Therefore, it is not clear exactly what kind of motor skills are essential for a fire-fighter. Analysing the tests for men, it can be concluded that speed endurance, speed, and strength of the muscles of the shoulder girdle and arms are important. On the other hand, while analysing tests for women, one can come to the conclusion that strength of the abdominal muscles and muscles of the shoulder girdle and arms, and agility are essential [14]. One might have the impression that physical fitness tests for fire-fighters were chosen quite randomly and inconsistently. In the army and the police, a discussion on the standardization of physical fitness tests for officers (soldiers) of both genders has been on-going for a long time. The first changes were implemented in the police in which the same physical fitness tests were introduced for candidates. This consistency was not kept while testing the fitness level of police officers on duty. In the other uniformed services, todate, no changes have been introduced. There is probably a lack of awareness among the decision-makers that physical fitness tests are used to determine the suitability to the position, irrespective of gender.

Analysing results of surveys carried out among candidates for professional soldiers in the General Tadeusz Kościuszko Military Academy of the Land Forces, revealed that up to $3 / 4$ of the of polled cadets believed that physical fitness tests should be uniform for soldiers of both genders. Respondents in favour of the same tests very accurately and succinctly justified their opinion by claiming that during military action there will be no distinction between male and female soldiers - quite simply, the task in hand has to be carried out. Furthermore, during joint actions, partnership and cooperation are expected since the team (task group) is only as strong as its weakest soldier [19].

The current tests of physical fitness in terms of movement structure and energy requirements, to a small extent relate to the potential tasks to be performed by a fire-fighter. Although general physical fitness tests are carried out in the fire brigade, in general they do not correlate with the tasks (activities) performed by a fire-fighter during rescue operations [17, $18,20]$. Paradoxically, the anaerobic endurance test that correlates the most with tests that include typical fire-fighter activities during rescue operations, is the least trained motor capacity in the examined group. Additionally, analysis of the anaerobic-aerobic speed endurance in the subsequent years revealed a gradual decrease of these abilities among the examined fire-fighters. To sum up the above-discussed issues, it should be clearly stated that the physical fitness tests should reflect the potential fire-fighter's tasks - focused and special physical fitness. Considering that the activities of the firefighter take place in situations of chronic stress, long-term action, and precision in rescue operations, it is advisable to take into consideration an evaluation of coordination motor skills while preparing future physical fitness tests [21, 22].

\section{CONCLUSIONS}

It was found that during the 3-year's year education in the Main Fire Service School, the general fitness level of the students increased, while there was a decrease in speed 
endurance (anaerobic-aerobic), which are basic motor skills of a firefighter.

The presented study suggests that in the Main Fire Service School physical education classes and other activities requiring increased physical activity do not adapt the students to make physical efforts related to their future profession.

Further research should aim at developing the physical fitness test which evaluates the physical fitness of students at the Main Fire Service School, i.e. reflecting the movement in terms of structure and energy which are basic steps for a firefighter.

\section{REFERENCES}

1. Perroni F, Cignitti L, Cortis C, Capranica L. Physical fitness profile of professional Italian firefighters: differences among age groups. Appl Ergon. 2014; 45(3): 456-61.

2. Von Heimburg E, Medbø JI, Sandsund M, Reinertsen RE. Performance on a work-simulating firefighter test versus approved laboratory tests for firefighters and applicationts. Int J Occup Saf Ergon. 2013; 19(2): 227-43.

3. Beach TA, Frost DM, McGill SM, Callaghan JP. Physical fitness improvements and occupational low-back loading an exercise intervention study with firefighters. Ergonomics, 2014; 57(5): 744-63.

4. Kong PW, Suyama J, Cham R, Hostler D. The relationship between physical activity and thermal protective clothing on functional balance in firefighters. Res Q Exerc Sport. 2012; 83(4): 546-52.

5. Smith DL, Petruzzello SJ, Kramer JM, Misner JE. Physiological, psychophysical and psychological responses of firefighters to firefighting training drills. Aviat Space Environ Med. 1996; 67(11): 1063-8.

6. Williams-Bell FM, Villar R, Sharratt MT, Hughson RL. Physiological demands of the firefighter candidate physical ability test. Medicine and Science in Sports and Exercise. 2009; 41(3): 653-662.

7. Gledhill N, Jamnik VK. Characterization of the physical demands of firefighting. Canadian Journal of Sports Science. 1992; 17(3): 207-213

8. ODPM, 2004. Operational Physiological Capabilities of Firefighters. Literature Review and Research Recommendations. Fire Research Technical Report 1/2005. London.

9. Rakowski A, Siwko F, Lewicki W. Ocena sprawności fizycznej kandydatów do Szkoły Głównej Służby Pożarniczej w Warszawie. In: Współczesne kierunki rozwoju kultury fizycznej w formacjach obronnych. (Evaluation of physical fitness candidates to Fire Service University. In:Contemporary trends in the development of physical culture in defensive formations). (Eds.) Kalina RM, Klukowski K, Jędrzejak K, Kaczmarek A. Warszawa, 2000; t. 5, 72-74 (in Polish).
10. Clark S, Rene A, Theurer WM, Marshall M. Association of body mass index and health status in firefighters. J Occup Environ Med. 2002; 44: 940-6.

11. Storer TW, Dolezal BA, Abrazado ML, Smith DL, Batalin MA, Tseng $\mathrm{CH}$, Cooper CB. Firefighter health and fitness assessment: a call to action. J Strength Cond Res. 2014; 28(3): 661-71.

12. Franke WD, Anderson DF. Relationship between physical activity and risk factors for cardiovascular disease among law enforcement officers. J Occup Med 1994; 36: 1127-32.

13. Kales SN, Elpidoforous SS, Costas ACh, Christiani DC. Emergency duties and deaths from heart disease among firefighters in the Unites States. The New England Journal of Medicine 2007; 356: 1207-1215.

14. Rozporządzenie Ministra Spraw Wewnętrznych i Administracji z dnia 27 października 2005 r. w sprawie zakresu, trybu i częstotliwości przeprowadzania okresowych profilaktycznych badań lekarskich oraz okresowej oceny sprawności fizycznej strażaka Państwowej Straży Pożarnej (Dz. U. Nr 261, poz. 2191) (Directive of the Minister of Internal Affairs and Administration on 27 October 2005 on the scope, manner and frequency of the periodic preventive medical examinations and periodic physical fitness assessment of fire-fighters serving in the State Fire Service) (in Polish).

15. Przewęda R, Trześniowski R. Sprawność fizyczna polskiej młodzieży w świetle badań z roku 1989 (Physical fitness of Polish youth in the light of research from 1989). Studia i Monografie, AWF Warszawa, 1996 (in Polish).

16. Roberts MA, O’Dea J, Boyce A, Mannix ET. Fitness levels of firefighter recruits before and after a supervised exercise training program. J Strength Cond Res 2002; 16: 271-7.

17. Matthew R, Rhea MR, Alvar BA, Gray R. Physical fitness and job performance of firefighters. J Strength Cond Res. 2004; 18(2): 348-352.

18. Strating M, Bakker RH, Dijkstra GJ, Lemmink KA, Groothoff JW. A job-related fitness test for the Dutch police. Occup Med (Lond). 2010 Jun; 60(4): 255-60. doi: 10.1093/occmed/kqq060.

19. Tomczak A, Bembnowicz M. Poglądy żołnierzy na zróżnicowane ze względu na płeć testy sprawności fizycznej stosowane w Siłach Zbrojnych RP. (The views of soldiers on the diverse by gender physical fitness tests used in the Polish Armed Forces), 2013. W: M. Sokołowski (red.) Morfofunkcjonalne aspekty służb mundurowych. Seria Monografie 4. PTNKF, s. 141-150. Abstract in English.

20. Oksa J, Rintamaki H, Takatalo K, Makinen T, Lusa S, Lindholm H, Rissanem S. Firefighters muscular recovery after a heavy work bout in the heat. Appl Physiol Nutr Metab. 2013; 38(3): 292-9.

21. Dąbrowski J, Ziemba A, Tomczak A, Mikulski T. Physical performance of health men expose to long exercise and sleep deprivation. Med. Sportiva 2012; 16(1): 6-11. doi: 10.5604/17342260.987837.

22. Tomczak A. Impact of a 3-day survival training of special operations unit soldiers on selected coordination motor skills. Arch Budo 2013; 3: $167-172$. 